\title{
Effects of Temperature and Salinity on Coral Bleaching in Laboratory
}

\author{
Kamonphon Patthanasiri, Thaithaworn Lirdwitayaprasit, Thamasak Yeemin, Ing-on Thongcamdee, and \\ Nantapak Potisarn
}

\begin{abstract}
Coral bleaching occurs when cell density or the concentration of photosynthetic pigments of the endosymbionts, zooxanthellae are decreased. This incident may possibly be caused by some environmental stresses, especially under conditions of elevated temperature, decrease in water salinity, or a combination of these factors. To determine the role of temperature and salinity on zooxanthellae and coral bleaching this study was conducted in aquariums under laboratory conditions on cauliflower coral Pocillopora damicornis. The samples were collected from three sites around Samaesan Island, Chonburi, Thailand. Three sets of experiments were conducted at three levels of temperature: room temperature 27 (control), 30, and $33{ }^{\circ} \mathrm{C}$ respectively. At each temperature level, three levels of salinities; 10,20 and 30 (control) psu were tested as well. Coral bleaching percentage and zooxanthellae density in the water column were observed every 6 hours during the period of 72 hours. The results showed that when coral exposed to the highest temperature $\left(33^{\circ} \mathrm{C}\right)$ under the lowest salinity (10 psu), 50-90\% bleaching was found and higher symbiont densities in the water column were detected. These results suggested that the combination of the high temperature and low salinity had synergistic effects on coral bleaching and zooxanthellae.
\end{abstract}

Index Terms-Bleaching, salinity, temperature, zooxanthellae.

\section{INTRODUCTION}

Bleaching or the paling of coral color occurs when cell densities or/and the concentration of photosynthetic pigments of zooxanthellae in coral are decreased [1], [2] which may result from some environmental stresses such as an increase in temperature, solar radiation, disease, decreased salinity, sedimentation, inorganic nutrients, or a combination of these factors. Widespread coral bleaching has mainly been observed where daily sea surface temperature exceeds the mean summer maximum temperature by only $1-2{ }^{\circ} \mathrm{C}$ [3]

In recent decades, coral bleaching has become more severe resulting in a mass mortality of corals. Coral bleaching has increased in frequency, intensity and covered a larger

Manuscript received May 15, 2021; revised September 8, 2021. (The study is a part of the dissertation of the Department of Marine Science, Chulalongkorn University)

Kamonphon Patthanasiri, Thaithaworn Lirdwitayaprasit, and Ing-on Thongcamdee are with the Department of Marine Science, Chulalongkorn University, Thailand (e-mail: nune_pattha@hotmail.com, thaithaworn.1@chula.ac.th,ingon_nun@hotmail.com).

Thamasak Yeemi is with the Department of Biology, Ramkhamhaeng University, Thailand (e-mail: thamasakyeemin@yahoo.com).

Nantapak Potisarn is with the Kanchanaburi Inland Aquaculture Research and Development Center, Department of Fisheries, Thailand (e-mail: taekizaa.np@hotmail.com). geographic scale. The frequency and severity of bleaching events occurred under thermal stress. Due to the increased temperature, the growth rate, density and photosynthetic efficiency were decreased because of its effect on photosynthesis of zooxanthellae, especially at $32-34{ }^{\circ} \mathrm{C}$. [4]

The cause of coral bleaching is not only from the increase in temperature but also light and salinity intensity as well. For instance, Reference [5], [6] reported the salinity (especially hyposalinity) effect on the rates of photosynthesis of zooxanthellae. Moreover, the combination of high temperature and low salinity treatment may aggravate the effects of coral bleaching. [7], [8]

In Thailand, reported severe bleaching as a result of the increasing sea surface temperature from $29{ }^{\circ} \mathrm{C}$ to $30{ }^{\circ} \mathrm{C}$ for long periods in 2010 [9] and the years after, the severe flooding during the monsoon season in Thailand in the year 2011 diluted seawater around Si Chang Island to $11 \mathrm{psu}$ which resulted in coral bleaching. [10]

In order to better understand and test the effects of temperature and salinity, both separately and in combination, toward the change of zooxanthellae in the cauliflower coral Pocillopora damicornis a laboratory condition was chosen. It was decided the range of temperatures investigated would be from 27 to $33{ }^{\circ} \mathrm{C}$ and the range of salinity from 10 to $30 \mathrm{psu}$. These tested conditions are similar to the natural conditions of the corals around Samaesan Island where the specimens were collected.

\section{METHOD}

\section{A. Research Organism}

This study examined the effects of temperature and salinity on cauliflower coral Pocillopora damicornis, a common shallow water scleractinian found throughout the Gulf of Thailand and dominant in the study area. The samples were collected from three sites around Samaesan Island, Chonburi province, Thailand, namely: station A Khao Mha Jor (12.5986, 100.9465) station B Pla Muek Island (12.5871, 100.9438) and station C Had Tien diving point (12.5688, 100.9602)

\section{B. Coral Collection and Culturing}

The cauliflower corals Pocillopora damicornis were randomly collected at the depth of 1.5-4 m. from the three sites around Samaesan Island. Fragmentation of the coral was carried out and nursed for two months at Khao Mha Jor station. Just before the experiment, all samples were immediately brought to the laboratory at Eastern Gulf Fisheries and Development Center, Rayong. 


\section{Experimental Setup}

To test the effects of temperature and salinity on coral bleaching, this study carried out three experiments at room temperature 27 (control) 30 and $33{ }^{\circ} \mathrm{C}$ respectively. In each experiment at the set temperature, three levels of salinities; 10,20 and 30 (control) psu were also tested. The nubbins were randomly distributed in three aquariums. Each aquarium is divided into three compartments, (Station A Khao Mha Jor, B - Pla Muek Island, and C - Had Tien diving point). In each aquarium, seawater within the compartment is aerated, recirculated, and the aquariums were each placed under lights with an intensity of about 4,000 lux on a 12 hour photoperiod without feeding.

At 30 psu salinity one set of aquariums was kept at $27^{\circ} \mathrm{C}$ as control. The other aquariums were set for testing at 30 and 33 ${ }^{\circ} \mathrm{C}$ where the temperature was adjusted at the rate of $+1{ }^{\circ} \mathrm{C}$ per day until the temperature reached the set level. Once all aquariums reached the set temperature, the experiments were then started.

On the other hand, in the test for salinity effect one aquarium was set aside at $30 \mathrm{psu}$ as control while the other aquariums for testing at 20 and 10 psu their salinity were decreased at the rate of 5 psu for every 6 hours until the set salinities were reached and the experiments started.

\section{Measurement on Degree of Bleaching by Coral Health Chart}

Coral bleaching percentage was measured by a coral health chart (provided by the University of Queensland) that recorded changes in coral colour.

1) Select the lightest area, avoiding the tips of branching areas.

2) Hold the colour chart next to the selected area.

3) Rotate the chart until you find the closest colour match.

4) Record the matching colour code along with coral type on the data sheet.

5) Repeat step 1-4 for the darkest area.

\section{E. Cell Morphology Observation}

In all treatments during the experimental period, Cell morphology of zooxanthellae in the water column was also observed in shape, size (diameters), color, organelles and others

\section{RESULtS}

\section{A. Symbiont Densities in the Water Column}

Prior to starting the experiment, symbiont cells in the water column counts range from 0 to 2 cells $/ \mathrm{ml}$. During the period of experimentation at $30 \mathrm{psu}$, zooxanthellae in the water column were not found at the control temperature $\left(27^{\circ} \mathrm{C}\right)$. Very low symbiont densities in the water column were observed at the high temperature levels $\left(30\right.$ and $\left.33{ }^{\circ} \mathrm{C}\right)$ with the symbiont densities ranging from $0-2$ cells $/ \mathrm{ml}$.

At the $20 \mathrm{psu}$ level, the symbiont densities range from $44-772$ cells $/ \mathrm{ml}$. at both 30 and $33{ }^{\circ} \mathrm{C}$. While the highest symbiont densities were found to be at the lowest salinity level (10 psu) especially during exposure to higher temperature, that of $33{ }^{\circ} \mathrm{C}$, with up to $1870 \mathrm{cells} / \mathrm{ml}$. from
Had Tien diving point station.

Results in this study showed that the symbiont started to leave their hosts once the salinity decreased and the temperature increased with an exception at 20 psu where the symbiont density in the water column at $30{ }^{\circ} \mathrm{C}$ was higher than that of $33{ }^{\circ} \mathrm{C}$. The highest symbiont densities in the water column were detected in the lowest salinity (10 psu) under the highest temperature treatments $\left(33^{\circ} \mathrm{C}\right)$. Moreover, those cells in the water column were similar to normal cells in shape and size but they were clearly pale in colour and had less cytoplasmic organelles than the normal cells. [Fig 1 and 2]

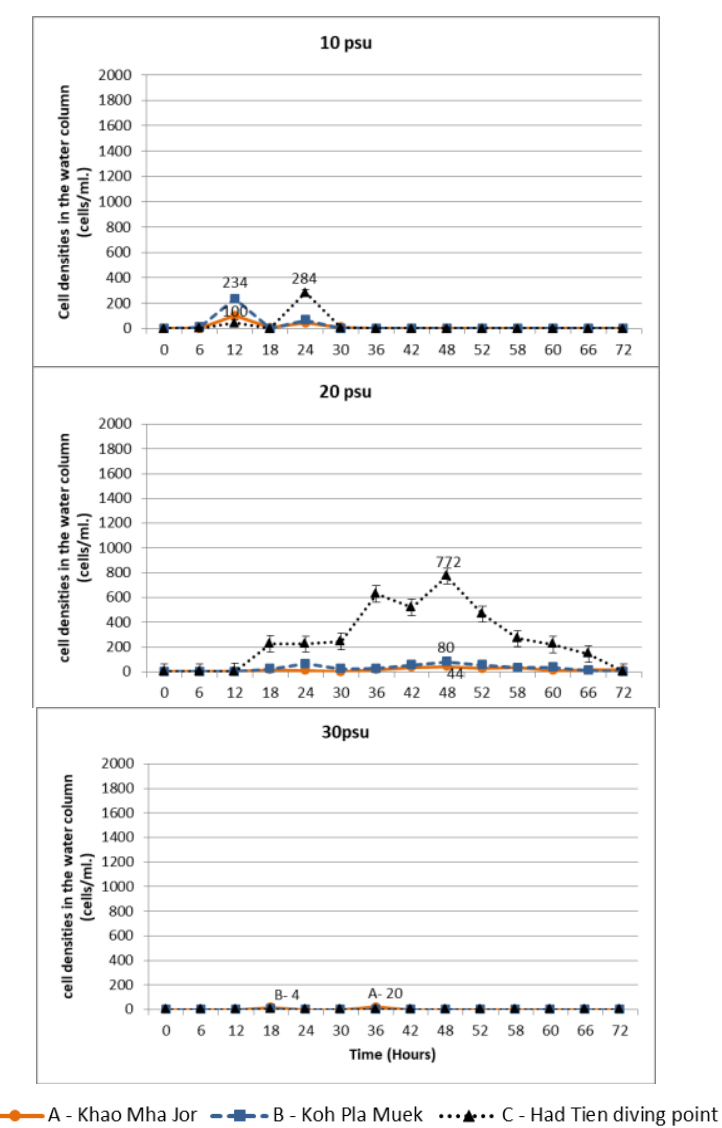

Fig. 1. Symbiont densities in the water column at the temperature levels 30 oC under the 10, 20 and 30 psu.

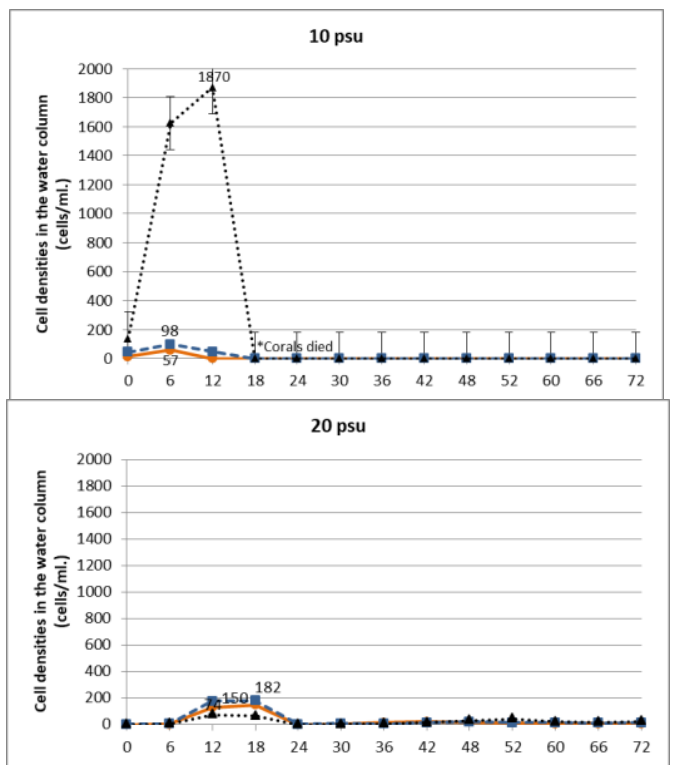




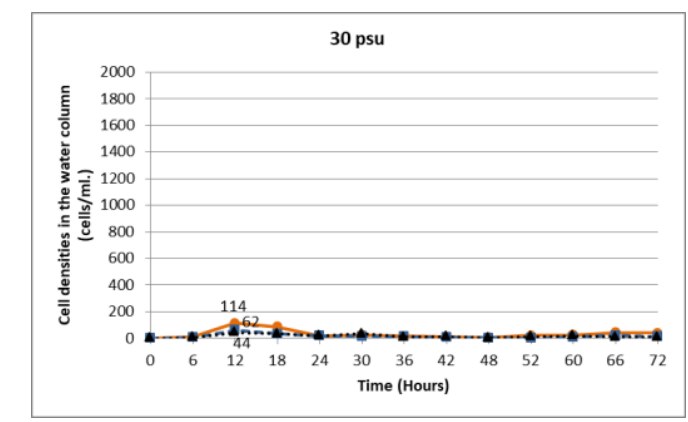

$\longrightarrow$ A - Khao Mha Jor - - B - Koh Pla Muek …... C - Had Tien diving point

Fig. 2. Symbiont densities in the water column at the temperature levels 33 oC under the 10, 20 and 30 psu.

\section{B. Coral Bleaching (Measured by Coral Health Chart)}

At the control temperature $27^{\circ} \mathrm{C}$, under the control salinity of 30 psu and 20 psu level the normal coral branches (no bleaching) were found but under the lowest salinity level of 10 psu $50-70 \%$ bleaching was found at all stations (Lightest area color: Station A - D1 65\%, Station B - D1 50\%, and Station C - D1 70\%). [Fig 3]

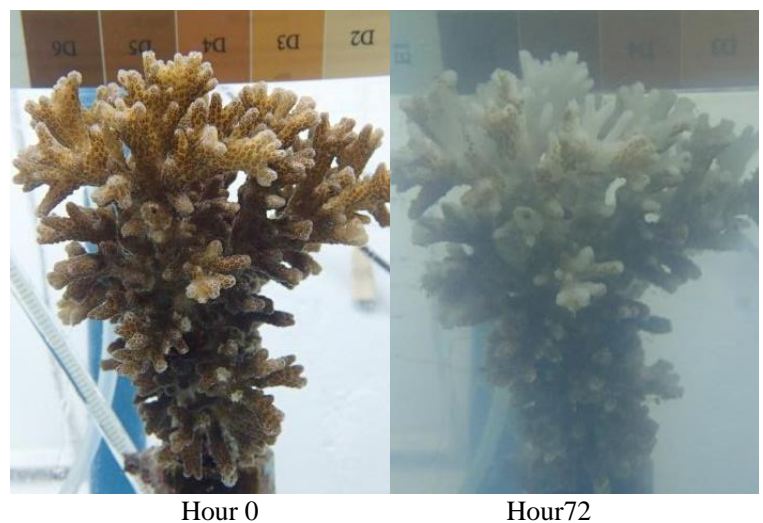

Fig. 3. Coral branches at the control temperature $(27 \mathrm{oC})$ under $10 \mathrm{psu}$ at Hour 0 and Hour 72

At the midrange $30^{\circ} \mathrm{C}$, under the control salinity (30 psu) it was found that there were normal coral branches (no bleaching). Under the 20 psu treatment bleaching had occurred after 36 hours. At 72 hours, the area of bleached corals reached 5-50\% (Lightest area color: Station A - D2 $5 \%$, Station B - D1 10\% and Station C - D1 50\%).

In the lowest salinity treatment (10 psu), $40-70 \%$ of bleaching was found after 18 hours and coral branches from Station A died, corals from Station B died after 24 hours, whereas corals from Station $\mathrm{C}$ remained alive, as shown in Fig. 4.
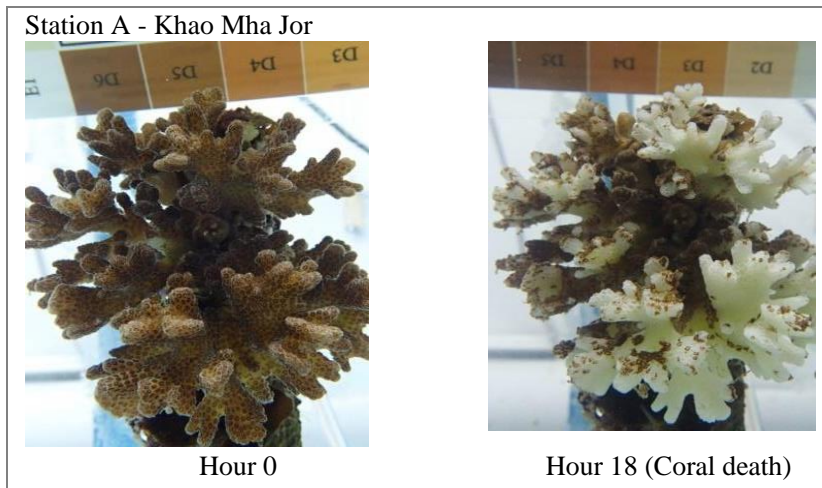

Hour 18 (Coral death)

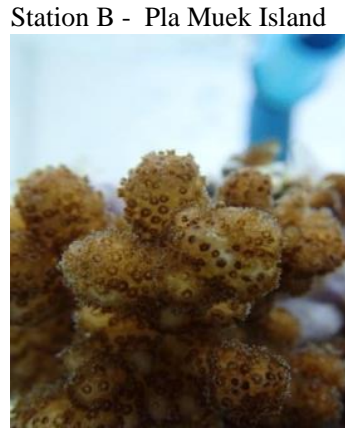

Hour 0

Station C - Had Tien diving point

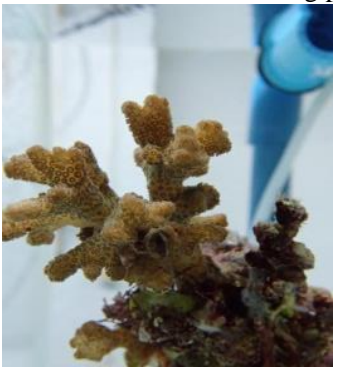

Hour 0

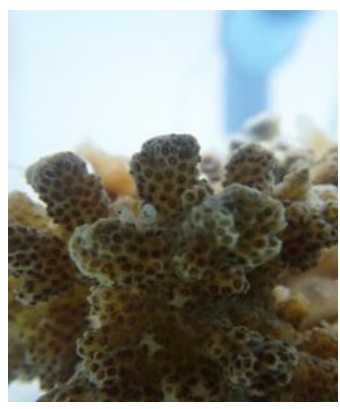

Hour 24 (Coral death)

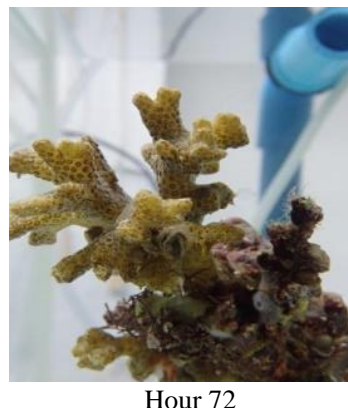

Hour 72

Fig. 4. Coral branches from 3 stations a). Khao Mha Jor, b). Pla Muek Island and c). Had Tien diving point at $30 \mathrm{oC}$ under the lowest salinity (10 psu).

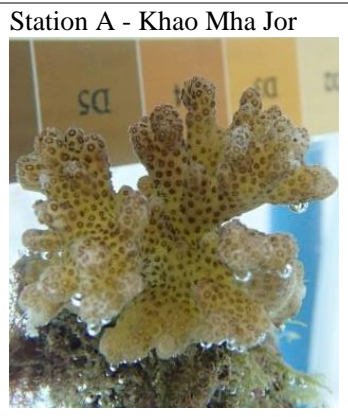

Hour 0

Station B - Pla Muek Island

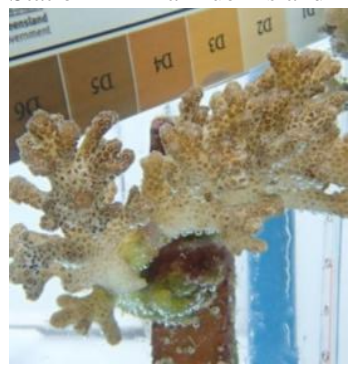

Hour 0

Station C - Had Tien diving point

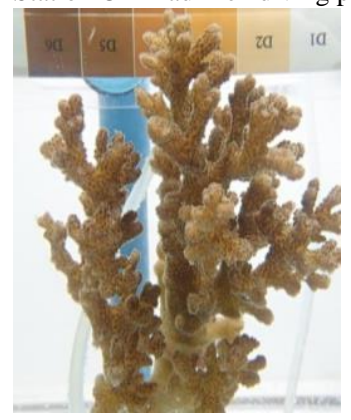

Hour 0

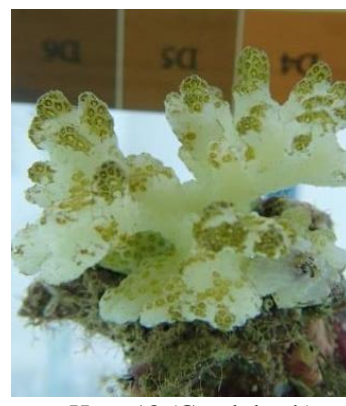

Hour 18 (Coral death)

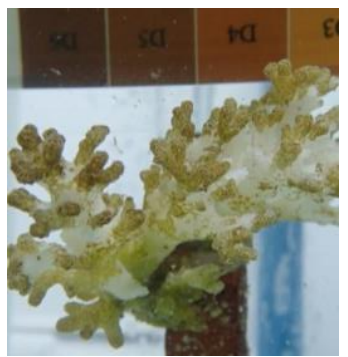

Hour 18 (Coral death)

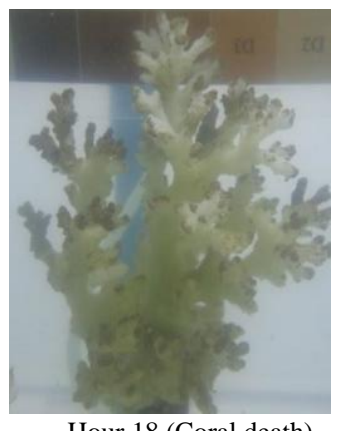

Hour 18 (Coral death)

Fig. 5. Coral branches from 3 stations a). Khao Mha Jor, b). Pla Muek Island and c). Had Tien diving point at $33{ }^{\circ} \mathrm{C}$ under the lowest salinity (10 psu). 
For the coral exposed to the lowest salinity of $10 \mathrm{psu}$, 50-90\% bleaching (Lightest area color: Station A - D1 90\%, Station B - D1 70\% and Station C - D1 90\%) took place before their death on the 18th hour, as shown in Fig. 5.

\section{DISCUSSION}

The highest number of zooxanthellae released and coral bleaching were detected in the lowest salinity (10 psu) under the highest temperature $\left(33{ }^{\circ} \mathrm{C}\right)$ treatments. This result indicates that the high temperature and low salinity affect zooxanthellae and cause coral bleaching. Under the increased temperature condition, growth rate density and photosynthetic efficiency of zooxanthellae were decreased because of the elevated temperature, especially at $32-34{ }^{\circ} \mathrm{C}$ where it affects the photosynthesis of zooxanthellae in living corals. [11], [12] However, the tolerance of symbiotic algae to temperature stress may vary depending on host coral species. Moreover, Reference [5] reported the changing in salinity, especially hyposalinity, affected the rates of photosynthesis of zooxanthellae. Beyond that the reduction in salinity in surface waters caused massive mortality of coral reef organisms.

Under the control salinity treatment (30 psu) the stressed coral had changes to the darkest area moving from D6 to D4 but did not bleach the coral to a white skeleton (D1 color) even at the exposure of $33{ }^{\circ} \mathrm{C}$. On the other hand, 50-70\% bleaching was found at all stations when under the lowest salinity level of $10 \mathrm{psu}$, including the corals exposed to the control temperature $\left(27{ }^{\circ} \mathrm{C}\right)$. Since the salinity at every temperature test shows a more intense effect on the number of zooxanthellae released and coral bleaching, the result may differ from the widespread belief that seawater temperature is the main factor inducing coral bleaching. That raised a question of why salinity becomes a stronger inducer than temperature.

In our experiments, the tests have been carried out in aquariums that can contain limited amounts of seawater. In addition, the water in each aquarium was under controlled conditions and was uniform in water quality all around the tested specimens. On the contrary, in nature the cauliflower corals fill the space on the seafloor in both the horizontal and vertical plain. It is necessary to point out the differences between the condition of water mass in the aquarium and in nature. Uniformity of water quality was maintained in the aquariums while in nature uniformity in water quality in both the horizontal and vertical plain is nearly impossible due to the actions of water flow both by wave and intertidal current, variation in light intensity during the daytime, concentration of suspended particulates in water mass, the balance between replenishment rate and bleaching of the coral, and other unknown factors. Since the tests were carried out only for salinity and temperature, emphasis will be made on only these two factors.

In conclusion, in this study we found the highest bleaching percentage when corals exposed to the lowest salinity (10 psu) at every temperature level. Moreover, we found 50-90\% bleaching (highest percentage) and the highest symbiont densities in the water column when corals were exposed to the highest temperature level $\left(33^{\circ} \mathrm{C}\right)$ under the lowest salinity level (10 psu). It suggests that the combination of high temperature and low salinity can affect the coral bleaching and zooxanthellae in living corals. The high temperature and low salinity treatment had synergistic effects on scleractinian coral fragment. [7], [13]

\section{CONFLICT OF INTEREST}

The authors declare that we have no conflict of interest.

\section{AUTHOR CONTRIBUTIONS}

Kamonphon Patthanasiri, Thaithaworn Lirdwitayaprasit and Thamasak Yeemin carried out the research design and analyzed the data; Kamonphon Patthanasiri, Ing-on thongcamdee and Nantapak Potisarn carried out the field and laboratory study. The authors' contribution is reflected in all the research approved in its final version.

\section{ACKNOWLEDGMENT}

The authors would like to thank the Royal Thai Marine Corps for the assistance with the sample collecting and The Eastern Gulf Fisheries and Development Center, Rayong for the laboratory. This study was supported by the Plant Genetic Conservation Project under the Royal Initiative of Her Royal Highness Princess Maha Chakri Sirindhorn, the graduate school Chulalongkorn University, and the Science Achievement Scholarship of Thailand.

\section{REFERENCES}

[1] G. P. Podestá and P. W. Glynn, "Sea surface temperature variability in Panama and Galapagos: Extreme temperature causing coral bleaching," Journal of Geophysical Research: Oceans, vol. 102, pp. 15749-15759, July 1997.

[2] T. C. Jeunesse and R. K. Trench, "Biogeography of two species of Symbiodinium (Freudenthal) inhabiting the intertidal sea anemone Anthopleura elegantissima (Brandt)," The Biological Bulletin, vol. 199, pp. 126-134, Oct 2000.

[3] R. J. Jones, O. Hoegh-Guldberg, A. W. D. Larkum, and U. Schreiber, "Temperature induced bleaching of corals begins with impairment of the $\mathrm{CO}_{2}$ fixation mechanism in zooxanthellae," Plant Cell and Environment, vol. 21, pp. 1219-1230, March 2002.

[4] R. Rodolfo-Metalpa, C. Richard, D. Allemand, C. N. Bianchi, C. Morri, and C. Ferrier-Pagès, "Response of zooxanthellae in symbiosis with the Mediterranean corals Cladocoracaespitosa and Oculinapatagonica to elevated temperatures," Marine Biology, vol. 150, pp. 45-55, May 2006.

[5] C. Ferrier-Pages, J. P. Gattuso, and J. Jaubert, "Effect of small variations in salinity on the rates of photosynthesis and respiration of the zooxanthellae coral Stylophora pistillata," Marine Ecology Progress Series, vol. 181, pp. 309-314, May 1990.

[6] R. Berkelmans, A. M. Jones, and B. Schaffelke, "Salinity thresholds of Acropora spp. on the Great Barrier Reef," Springer-Verlag, vol. 31, pp. 1103-1110, July 2012.

[7] M. Dias, C. Madeira, N. Jogee, A. Ferreira, R. Gouveia, H.Cabral, M. Diniz, and C. Vinagre, "Oxidative stress on dcleratinian coral fragments following exposure to high temperature and low salinity," Ecological Indicators, vol. 107, Dec 2019.

[8] R. A. Kinzie, M. Takayama, S. R. Santos, and M. A. Coffroth, "The adaptive bleaching hypothesis: experimental tests of critical assumptions," The Biological Bulletin, vol. 200, pp. 51-58, Nov 2000.

[9] R. P. Dunne, "The record of sea temperature during the 2010 coral bleaching at Phuket, Thailand-different datasets, different perspectives-unexplained errors in hadisst 1.1.," Phuket Marine Biological Center Research Bulletin, vol. 71, pp. 11-18, 2012.

[10] T. Yeemin, "Climate change impacts and implications. Synthesis of status and knowledge on impacts, recovery and management of coral reefs from coral bleaching phenomenon," 2011.

[11] G. Yamashita et al., "Acropora recruits harbor "rare", Symbiodinium in the environmental pool," Springer-Verlag, vol. 32, pp. 355-366, Nov 2012. 
[12] K. R. Trench, "The cell biology of plant - Animal symbiosis," Ann. Rev. Plant Physiol, vol. 30, pp. 485-531. 1979.

[13] Z. Zhou, S. Zhao, J. Ni, Y. Su, L. Wang, and Y. Xu, "Effects of environmental factors on C-type lectin recognition to zooxanthellae in the stony coral Pociilopora damicornis," Fish and Shellfish Immunology, vol. 79, pp. 228-233, Aug 2018.

Copyright $(2022$ by the authors. This is an open access article distributed under the Creative Commons Attribution License which permits unrestricted use, distribution, and reproduction in any medium, provided the original work is properly cited ( $\underline{\text { C BY 4.0) }}$.

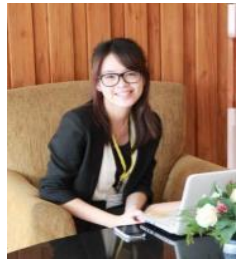

Kamonphon Pattanasiri is Ph.D. student of the Department of Marine Science, Faculty of Science, Chulalongkorn University Bangkok, Thailand. She received her master degree in marine science (marine biology) from Faculty of Science, Chulalongkorn University. She has continued research on zooxanthellae, cultured zooxanthellae that isolated from some marine invertebrates. She researched the effects of temperature and salinity on zooxanthellae and coral bleaching and Use of the thermal tolerance strain of zooxanthellae for coral bleaching recovery, in laboratory.

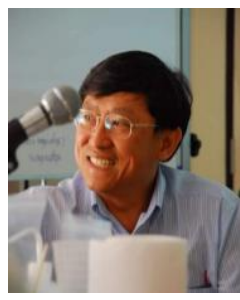

Thaithaworn Lirdwitayaprasit is an associate professor of the Department of Marine Science, Faculty of Science, Chulalongkorn University, Thailand. He received his doctoral degree in marine ecological chemistry from Ehime University, Japan. $\mathrm{He}$ has continued research on marine ecology; physiological, ecological and biochemical studies of red tide organisms; focusing on Harmful effects and management of red tide phenomena.

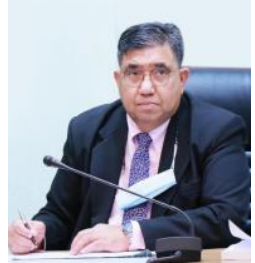

Thamasak Yeemin is an associate professor of the Department of Biology, Faculty of Science, Ramkhamhaeng University, Thailand. $\mathrm{He}$ is the president of Marine Science Association of Thailand. He received his doctoral degree in marine biology from Kyushu University, Japan. He has continued research on coral recruitment, distribution and abundance of juvenile corals, Intra and interspecific interactions in a scleractinian corals, sexual reproduction of scleractinian corals and coral reef ecosystem in Thailand.
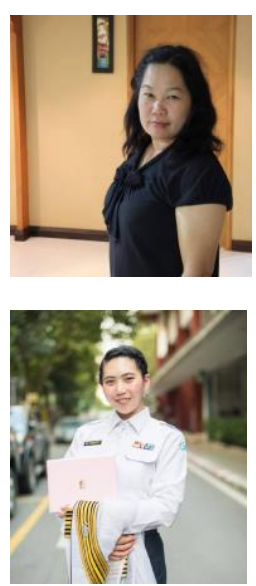

Ing-on Thongcamdee is an assistant researcher of associate professor Dr. Thaithaworn Lirdwitayaprasit, the Department of Marine Science, Faculty of Science, Chulalongkorn University. She has continued research on Marine Ecology; physiological, ecological and biochemical studies of red tide organisms; focusing on Harmful effects and management of red tide phenomena.

Nantapak Potisarn is a Marine Fishery Biologist of Department of Fisheries. She received her master degree in marine science from Chulalongkorn University. She has continued research on marine phytoplankton especially harmful algae, cultured some of potentially harmful algal. She studies on the morphological and molecular characterization of benthic dinoflagellates. 